Island Studies Journal, Vol. 9, No. 1, 2014, pp. 7-22

\title{
Multi-levelling and externalizing migration and asylum: lessons from the southern European islands
}

Anna Triandafyllidou

European University Institute

Florence, Italy

Anna.Triandafyllidou@EUI.eu

\begin{abstract}
Southern European countries have come to constitute the most vulnerable external border of the European Union (EU) over the last decade. Irregular migration pressures have been acutely felt on the EU's southern sea borders, and particularly on four sets of islands: Canary Islands (Spain), Lampedusa and Linosa (Italy), Malta, and Aegean Islands (Greece). This quartet is, to a large extent, used as stepping stones by irregular migrants and asylum seekers to reach the European continent. This paper studies the role of these islands as 'outposts' of a framework of externalization. It starts by discussing the notion of externalization and its different facets. It considers how externalization is linked to both fencing and gate-keeping strategies of migration and asylum control. The second part of the paper focuses on the special role of the island quartet with respect to the externalization web cast by national and EU-wide migration policies. It concludes with a critical reflection on the multi-level character of externalization policies and practices that occur both within the EU and between the EU and third countries.
\end{abstract}

Keywords: control; externalization; fencing; gatekeeping; irregular migration; islands

(C) 2014 - Institute of Island Studies, University of Prince Edward Island, Canada.

\section{Introduction: the challenge of migration at the EU's southern sea borders}

The European Union has paid increasing attention to the management of its external borders with a view to preventing and combating irregular migration. This has been an issue of top priority prior to the 2004 enlargement, enhancing cooperation and mutual training among border patrols in the EU 27, providing new member states in Central Eastern Europe with sophisticated equipment and advanced know how. Moreover, a European Neighbourhood Policy has been established which mainly aims at promoting friendly relations, political and economic stability in the EU's Eastern European 'neighbourhood' and thus both preventing immigration flows as well as externalizing their management and control to the neighbouring countries before irregular immigrants reach the EU external borders. The European Neighbourhood policy has been expanded to include the countries south of the EU in 20062007, when actually the focus of irregular migration concerns was at the western part of the Mediterranean and more specifically on Spain and the Canary islands.

Since 2006, the management of sea borders and in particular the role of islands as stepping stones to continental Europe has attracted increasing attention (also Bernardie-Tahir \& Schmoll, 2014; Triandafyllidou \& Maroukis, 2012). Indeed, 2006 can be signalled as the crisis year which marked a new period in South to North flows across the Mediterranean sea. 


\section{A. Triandafyllidou}

Four sets of islands, belonging to four different countries have become important stepping stones in the Mediterranean.

First, the Canary Islands, in the Atlantic, form part of Spanish territory and have been a preferred target destination for thousands of irregular migrants sailing off the shore of Mauritania and Senegal for a week-long journey to Tenerife. Irregular migrants apprehended upon arrival at the Canary islands have significantly fluctuated during the last decade, from less than 1,000 in 1999 up to 32,000 in 2006, and to a mere 340 people in 2011.

The second set of islands that has probably attracted the largest number of irregular migrants and asylum seekers during the last decade is the small island of Lampedusa $(4,500$ inhabitants), south of Sicily, and even smaller Linosa (450 inhabitants), situated between Lampedusa and Malta. Lampedusa has been receiving approximately 15,000 to 20,000 irregular immigrants and asylum seekers per year throughout the decade. Arrivals soared to more than 30,000 in 2008 but were reduced to less than 1,000 people in 2010 after the accords between the Italian and Libyan governments in 2009. Irregular migration and asylum seeker flows however soared again, to more than 51,000 arrivals, in the period January to September 2011 as a result of the Arab Spring turmoil in Tunisia and the civil war in Libya. While arrivals went down to approximately 15,000 in 2012, they have picked up again during 2013 to over 30,000 in the first 8 months of the year.

Some of the vessels setting off from northern Africa to Italy have been reaching the island state of Malta (also Mainwaring, this special issue). As a result, Malta has received some 1,500 to 2,000 irregular migrants and asylum seekers per year since 2002, a significantly large number for a small and overpopulated island that has a total of 420,000 inhabitants.

The fourth set of islands that has become an important stepping stone to continental Europe are some of the Aegean islands of Greece. They have been a target destination for mainly Asian but also African irregular immigrants and asylum seekers that seek to enter Europe through Turkey and cross the narrow straits from Turkish mainland to the islands of Mytilini (Lesvos) or Chios. Numbers of apprehended migrants and asylum seekers rose dramatically in the middle of the decade to an all time high of over 30,000 apprehensions in 2008 , fell significantly to 1,000 in 2011 , but picked up again during 2012 to reach more than 5,000 in the first 8 months of 2013.

This paper focuses on the islands as sites where the externalization of European asylum and migration policies unfolds. It starts by elaborating upon the notion of externalization, arguing that it comes in different guises and dimensions: there may be, for instance, an externalization of border controls (a fencing policy); or an externalization of asylum seeking or readmission (a gate-keeping policy). I thus consider the role of the islands in this web of externalization policies and practices, seeking to investigate the immediate and remote control aspects of externalization policies and practices. The islands thus serve as a case in point to understand better the modalities of externalization and the multiple forms that it can take.

The paper is organized as follows: section two elaborates on the notion and practice of externalization in its different facets. While section three reviews the size and features of irregular migration and asylum seeking flows at the southern sea borders of the European Union and specifically on the Canary Islands, Lampedusa and Linosa, Malta and the Aegean Islands and the policies adopted to confront these flows in each set of islands. In the concluding section, I discuss what are the multiple layers and different practices of externalization of EU migration and asylum policies at the islands, given their geographical position at the 'edge' of Europe. 


\section{Externalization of EU migration and asylum policies at the southern European islands}

The 'external dimension' of EU policies on migration and asylum is neither a new phenomenon nor a new topic of research. The need for extraterritorial control of asylum and migration and the links between migration or asylum policies and development aid or overall economic and political cooperation with countries of origin have been underlined by the European Parliament and the European Commission as early as 1987 (European Parliament, 1987). However, the 'external dimension' of EU migration and asylum control became a priority in 1999 with the Tampere Council conclusions. The Presidency conclusions stated that these concerns 'should be integrated in the definition and implementation of other Union policies and activities' including external relations (Lavenex, 2006, p. 333). The Seville Council Conclusions in 2002 stated that 'each future EU association or cooperation agreement should include a clause on "joint management of migration flows and compulsory readmission in the event of illegal immigration" (cited in Lavenex, 2006, p. 342). Partnership with countries of origin figured prominently in the Hague (2004) and Stockholm (2008) home affairs programs.

One of the early forms of externalization was the adoption of the 'safe third country' rule (Lavenex, 1999) which became the 'first safe country' principle introduced in the Dublin Convention of 1990 and further reaffirmed in the Dublin II Regulation of 2003 and in Dublin III Regulation of June 2013, which govern the asylum protocol in the EU today. During the enlargement negotiations, strict border controls became a conditionality principle for the Central European countries that were joining the EU. The externalization of European migration policies has been an integral part of the European Neighbourhood Policy which initially was implemented in the Eastern neighbourhood of the EU but was expanded to the South since 2007, incorporating the previously inter-governmental initiatives of the Barcelona process and the Euro-Mediterranean partnership into a Community framework (Triandafyllidou \& Ilies, 2010). The setting up of the Frontex agency in 2006 has further boosted the externalization of border controls since Frontex operations involved cooperation among specific countries of origin, a European country of destination and several member states which sent material and human resources to participate in the Frontex operations. Thus while Frontex has been created to assist and coordinate the management of the EU's external borders, it has also become a factor in the web of the externalization policies of the EU. In mid-2000s, the idea of creating off-shore asylum reception centres where asylum seekers would be detained while their claims would be assessed, without thus accessing EU territory, was pushed forward by Britain, Italy and Germany (Papagianni, 2006). Eventually such reception centres in third countries were not created; but these early developments showed how much several member states favoured the idea of externalizing asylum policy through creating extra territorial transit spaces where asylum could be managed. Indeed the idea was fundamentally at odds with the principles of liberal democracies as it involved that one state would apply its jurisdiction and pay for these centres which would however be located in the territory of another state.

In this paper, I suggest that we should distinguish between different types of externalization of migration and asylum policies in relation to their more specific areas of concern. Notably, we can speak of externalization of border controls, of return/readmission, and of asylum policies. Within each of these externalization domains, we can distinguish 


\section{A. Triandafyllidou}

between fencing and gate-keeping policies. Gate-keeping policies aim at restricting practical legal access to a nation and its institutions, while fencing measures actively target illegal migrants in order to arrest and then expel them. Typically, gate-keeping involves paper controls of people who seek to enter a country or who come voluntarily forward, while fencing involves detecting persons in hiding and trying to deter/stop those who seek to enter without appropriate authorization (Vogel, 2000; Triandafyllidou \& Ambrosini, 2011). Thus, for instance, EU neighbouring countries should guard their borders better so less (irregular/transit) migrants arrive at the EU external border. This can be done by neighbouring countries modifying their visa regimes towards other third countries (gate-keeping) or by building border control capacity (human resources, ICT equipment, other technical equipment) (fencing policies).

Before turning to the irregular migration and asylum seeking management on the islands, it is important to note that some externalization of migration controls is necessary as it is impossible to guard a border from one side only. Actually it is only authoritarian regimes that can seal their borders. Liberal democratic states always have more or less porous borders as they are constrained by organised interests and civil liberties' traditions in their efforts to reject unwanted migrants (Freeman, 1995; Guiraudon \& Lahav, 2000). Enlisting the cooperation of third countries means more development aid for them and more capacity building and to some extent some policy transfer concerning human rights standards. However, conditionality arrangements are often unrealistic because they pose too many requirements to countries of origin and transit than these last cannot fulfil (e.g. Triandafyllidou, 2009 on mobility partnerships). The externalization of EU migration and asylum policies actually prioritises control and efficiency over such other policy considerations as respect for fundamental rights, the right to asylum and overall concerns for social inequality between the global North and the global South.

\section{Southern European islands as pivotal zones of control}

In the sections that follow, I present the main irregular migration and asylum seeking flows to Europe's southern islands. The policies adopted by the states to which they belong to manage irregular migration flows are critically discussed.

\section{Spain and the Canary islands}

In 1999, Spain inaugurated the SIVE (Sistema Integrado de Vigilancia Exterior), a sophisticated system of electronic surveillance, with the aim to protect the southern coast of Spain and the Gibraltar strait from irregular migrant arrivals. Border surveillance and controls would not have been effective however if Spain had not managed to enlist the cooperation of Morocco in re-admitting its nationals. Until 2004, Moroccan authorities refused to readmit irregular migrants apprehended at the Spanish sea borders coming from Morocco unless they were its own nationals. However, under pressure from the EU, the Moroccan government accepted to readmit sub-Saharan Africans to its territory with a view to then returning them to their own countries of origin. Morocco also restricted its visa allowances for sub-Saharan African countries under pressure from Spain, so as to reduce transit migration through the country (Carling, 2007a). Thus, while during the period of 2002-2004 less than one third of the expulsion orders issued were executed, the rate rose to 92\% in 2007 (Spanish Interior Ministry, 
2008, cited in Gonzalez Enriquez, 2009). Irregular entry from Morocco was thus greatly reduced, while the pateras crossing the Gibraltar strait (only 9 miles wide) were systematically detected and their passengers returned to Morocco (Gonzalez Enriquez, 2008; Carling, 2007b).

Table 1: Migrants apprehended at sea borders, Spain: 1999-2011.

\begin{tabular}{|c|c|c|c|c|c|c|c|c|c|c|c|c|c|}
\hline & 1999 & 2000 & 2001 & 2002 & 2003 & 2004 & 2005 & 2006 & 2007 & 2008 & 2009 & 2010 & 2011 \\
\hline $\begin{array}{l}\text { Strait of } \\
\text { Gibraltar }\end{array}$ & 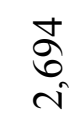 & $\frac{2}{1}$ & $\begin{array}{l}\stackrel{n}{\delta} \\
\dot{y} \\
\dot{J}\end{array}$ & $\frac{n}{6}$ & $\frac{\infty}{\infty} \underset{a}{a}$ & $\stackrel{\stackrel{n}{\sim}}{\stackrel{\sim}{N}}$ & $\begin{array}{l}8 \\
\delta \\
\circ\end{array}$ & $\begin{array}{l}\text { ㅇ } \\
\stackrel{2}{n} \\
\end{array}$ & $\begin{array}{l}\frac{a}{n} \\
i n\end{array}$ & $\begin{array}{l}\stackrel{m}{r} \\
\stackrel{y}{\forall}\end{array}$ & $\begin{array}{l}\hat{m} \\
\hat{n} \\
\text { n. }\end{array}$ & $\begin{array}{l}\stackrel{0}{+} \\
\underset{m}{m}\end{array}$ & $\stackrel{\varpi}{\beth}$ \\
\hline $\begin{array}{l}\text { Canary } \\
\text { Islands }\end{array}$ & $\frac{n}{\infty}$ & $\begin{array}{l}\stackrel{0}{\forall} \\
\stackrel{\sim}{v}\end{array}$ & $\frac{\beth}{\underset{\nabla}{J}}$ & $\begin{array}{l}n \\
\infty \\
a \\
a\end{array}$ & $\begin{array}{l}\infty \\
\infty \\
\text { n} \\
\sigma\end{array}$ & $\begin{array}{l}\stackrel{\sim}{\sim} \\
\stackrel{+}{+} \\
\infty\end{array}$ & $\frac{n}{\frac{n}{\gamma}}$ & $\frac{\infty}{\infty}$ & 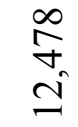 & $\frac{\vec{\infty}}{a}$ & $\begin{array}{l}\text { o } \\
\text { ゙ָ } \\
\text { d }\end{array}$ & 。 & m \\
\hline Total & $\begin{array}{l}\hat{b} \\
n \\
m\end{array}$ & $\frac{n}{\tilde{n}}$ & $\begin{array}{l}n \\
\infty \\
\infty\end{array}$ & $\begin{array}{l}? \\
6 \\
0 \\
0\end{array}$ & $\frac{0}{2}$ & $\begin{array}{l}n \\
\hat{\sigma} \\
n\end{array}$ & $\begin{array}{l}\infty \\
\stackrel{\infty}{\approx} \\
=\end{array}$ & $\frac{\infty}{\rho_{n}^{\infty}}$ & $\begin{array}{l}n \\
0 \\
\infty\end{array}$ & $\begin{array}{l}\stackrel{+}{\sim} \\
\stackrel{\oplus}{\sim}\end{array}$ & $\begin{array}{l}n \\
\infty \\
\text { Nh } \\
r\end{array}$ & $\begin{array}{l}\text { तु } \\
\text { m. }\end{array}$ & $\begin{array}{l}\underset{+}{+} \\
\dot{f}\end{array}$ \\
\hline
\end{tabular}

Source: Data for 1999-2010 based on Triandafyllidou \& Maroukis (2012), Table 2.1, p. 37. Data for 2011 based on data provided by the Spanish Coastguard authorities. Retrieved from http://migrantsatsea.wordpress.com/2012/02/13/increase-in-numbers-of-migrants-reachingspanish-coast-in-2011/, emphasis added. Note: $\mathrm{n} / \mathrm{a}=$ not available.

The better patrolling of the Moroccan Mediterranean coast led to the diversion of migrant routes southwards to the Atlantic coast of Morocco and further south, in the period 2006-2008, to Mauritania, Senegal and lately Gambia (see Map 1 below). The crossing was no longer to the southern Spanish region of Andalucia but to the Canary Islands in the Atlantic (which are also Spanish territory), at some 1,000 km (620 miles) west off the African coast. The Red Crescent organization in Mauritania estimated that, in the January-May 2006 period, at least 1,600 persons had died attempting the sea crossing (Triandafyllidou \& Maroukis, 2012).

Alongside increased efforts to effectively patrol not only the Gibraltar straits but also the Mauritanian and Senegalese coasts in cooperation with Mauritanian and Senegalese authorities and Frontex forces, the Spanish government undertook a 'diplomatic offensive' in West Africa. During 2007-2009, Spain signed readmission agreements with Cape Verde, Mali, Guinea Conakry, Guinea Bissau and Nigeria and varied forms of cooperation agreements with other states in the region, resulting in a notable improvement in border management and hence a sharp decrease of irregular arrivals from Africa (Gonzalez Enriquez, 2009). This externalization of the Spanish border control had its casualties: the Medecins Sans Frontieres reported maltreatment and important violations of human rights of Sub-Saharan African irregular migrants at the hands of Moroccan border guards (MSF, 2006). However, the success of this externalization of border control policies through a combination of fencing (Frontex) and gate-keeping (readmission agreements) strategies was notable: each year, numbers of 


\section{A. Triandafyllidou}

apprehensions have fallen consistently ${ }^{1}$. Apprehensions at the Spanish sea borders in 2011 stood at $1 \%$ of those during the crisis year of 2006 (Table 1 above).

Map 1: Flows of irregular migrants and asylum seekers towards South European border islands

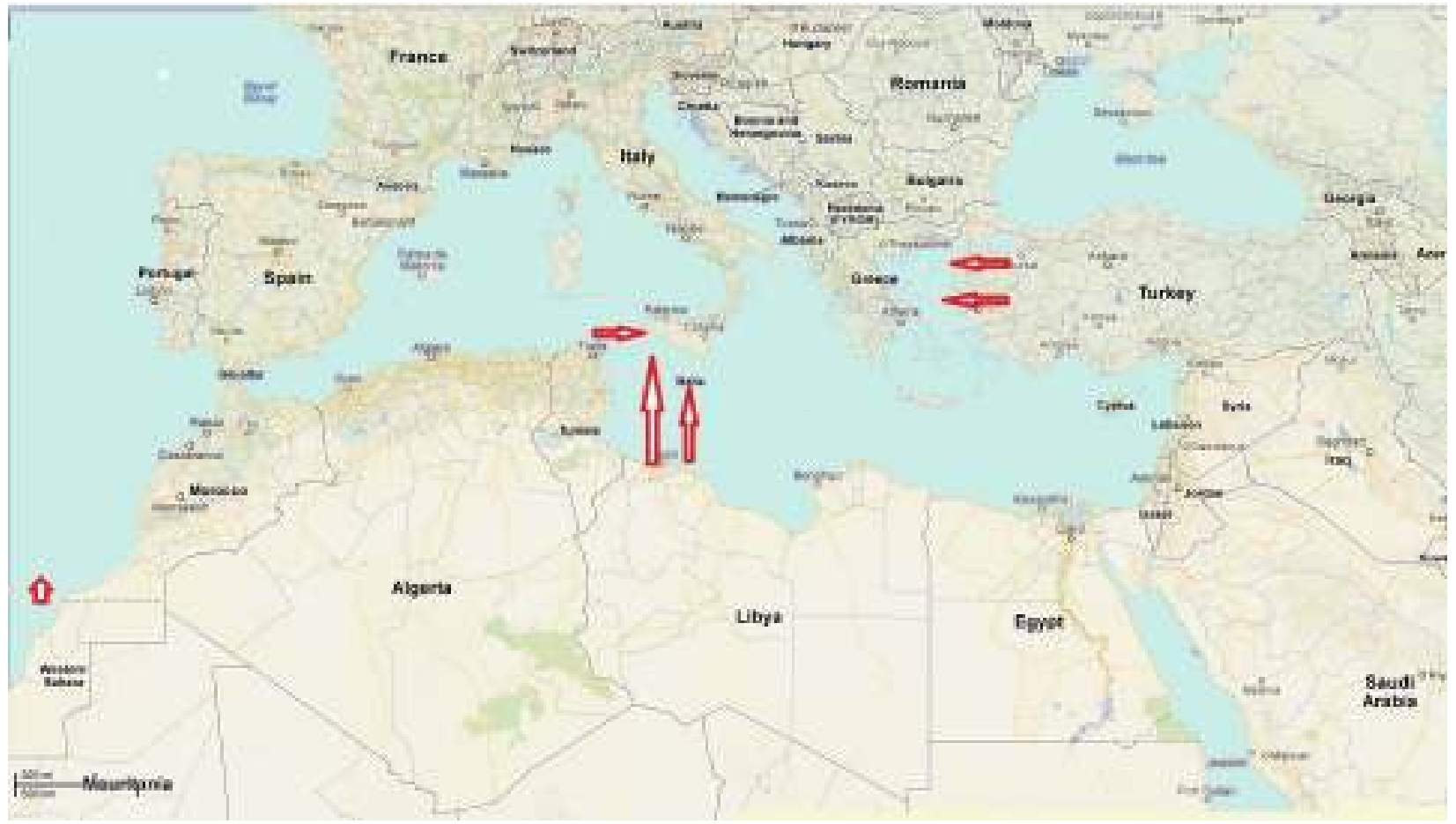

Source: Compiled by the author.

Of course, the success of the Spanish policies has to be seen in a wider Mediterranean context as irregular migration flows and smuggling routes usually do not stop but rather are re-directed to other points of entry.

\section{Lampedusa and Italy}

In recent years, Italy has been experiencing increasing irregular migration and asylum seeking flows arriving at its southern coasts from Libya. These flows are composed of migrants coming from northern Africa (Morocco, Libya, Algeria, Tunisia and Egypt) but also from sub-Saharan Africa, the Horn of Africa and more recently from Syria. Irregular migrants and asylum seekers, coming across the Mediterranean sea, land at the tiny island of Lampedusa, half way between the coast of Italy and Tunisia (Map 2 below). Lampedusa is $185 \mathrm{~km}$ (115 miles) south of the Sicilian coast, $290 \mathrm{~km}$ (180 miles) north of Libya, and only $120 \mathrm{~km}$ (75 miles) north of Tunisia.

\footnotetext{
${ }^{1}$ The fall in the number of apprehensions of irregular migrants at the Spanish southern borders does not mean that irregular migrants stopped arriving in Spain. It mainly means that they are not crossing the Spanish border illegally but rather probably choosing other means to enter the country.
} 
The Italian coastguard had stepped up its patrolling of the Lampedusa and Sicilian coasts since the mid 2000s; however, the results of these efforts were poor as the area to be patrolled is quite vast (see Map 1 above). Sea patrols near Sicily, Lampedusa and the tiny island of Linosa were not particularly effective since boats carrying irregular migrants were detected when they were too close to Italian shores and hence they had to be brought to harbour. Moreover, there is a controversy between Italy and Malta as to the patrolling of the larger sea area south of Malta and south of Italy. Maltese authorities object to the principle that migrants have to be disembarked in the closest port of the country that holds the Search and Rescue (SAR) area (Caffio, 2011). Italian authorities have accused their Maltese counterparts of not guarding the Italian sea waters effectively as they only stop boats that are in distress (also Mainwaring, 2008).

Table 2: Migrants apprehended at sea borders, Italy: 1999-2013.

\begin{tabular}{|c|c|c|c|c|c|c|c|c|c|c|c|c|c|c|c|}
\hline & 1999 & 2000 & 2001 & 2002 & 2003 & 2004 & 2005 & 2006 & 2007 & 2008 & 2009 & 2010 & 2011 & 2012 & 2013 \\
\hline $\begin{array}{l}\frac{2}{0} \\
\text { in }\end{array}$ & 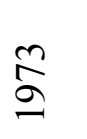 & 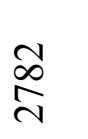 & $\begin{array}{l}\text { D } \\
\text { in }\end{array}$ & 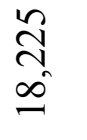 & $\begin{array}{l}\text { D } \\
0 \\
\pm \\
\Xi\end{array}$ & 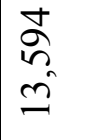 & 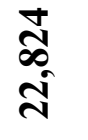 & 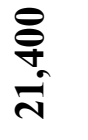 & $\begin{array}{l}n \\
\infty \\
n \\
n \\
0 \\
-1\end{array}$ & 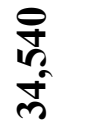 & \begin{tabular}{l} 
No \\
\multirow{N}{\infty}{} \\
$\infty$
\end{tabular} & ô & $\begin{array}{l}\infty \\
\stackrel{\infty}{+\infty} \\
\stackrel{+}{n} *\end{array}$ & \multirow{2}{*}{$\begin{array}{l}8 \\
\vdots \\
\text { in }\end{array}$} & \multirow{2}{*}{$\begin{array}{l}\text { * } \\
\stackrel{*}{8} \\
\stackrel{0}{0}\end{array}$} \\
\hline 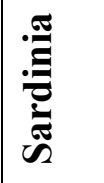 & & & & & & & 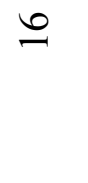 & $\widetilde{\infty}$ & 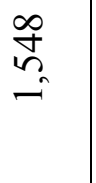 & $\overrightarrow{\widetilde{\sigma}}$ & $\stackrel{+}{+}$ & $\frac{\infty}{m}$ & $\stackrel{\widetilde{\pi}}{\beth}$ & & \\
\hline$\sum \stackrel{\vec{\pi}}{\underline{\pi}}$ & $\begin{array}{l}\text { बे } \\
\text { के }\end{array}$ & $\begin{array}{l}\text { D } \\
\infty \\
\stackrel{0}{N}\end{array}$ & $\frac{\text { f) }}{\stackrel{\text { in }}{0}}$ & $\frac{\partial}{\vec{\lambda}}$ & $\begin{array}{l}\vec{m} \\
\stackrel{ \pm}{ \pm}\end{array}$ & 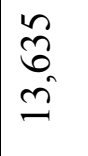 & $\begin{array}{l}\text { ๙ે } \\
\text { ते }\end{array}$ & $\begin{array}{l}0 \\
0 \\
\text { in } \\
\text { N }\end{array}$ & 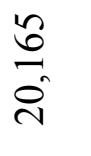 & $\begin{array}{l}\vec{n} \\
\hat{\sigma} \\
\text { n. }\end{array}$ & $\begin{array}{l}n \\
\hat{n} \\
a\end{array}$ & $\begin{array}{l}\stackrel{+}{+} \\
+ \\
+\end{array}$ & $\begin{array}{l}8 \\
\text { m } \\
\text { f }\end{array}$ & & \\
\hline
\end{tabular}

Source: Data for 1999-2008, UNODC (2010), Table 1, p. 11. Data for 2009-2011, Caritas Migrantes, Dossier Statistico, Roma, 2012, p131. Data on 2012 and 2013 based on Frontex data. Retrieved from http://www.frontex.europa.eu/news/update-on-central-mediterraneanroute-5wQPyW, emphasis added. * Data here refers to Lampedusa only. ** Until end of September 2013. Note: $\mathrm{n} / \mathrm{a}=$ not available.

Italy's cooperation with Libya intensified over the last decade despite concerns about the lawfulness of the Italian government's re-admission practices. As Klepp (2010, p. 4) argues, 'secrecy around the details of the agreements that were made and informality characterised the co-operation of Italy and Libya from the 1990s' especially concerning the collaboration between the security forces. Between August 2003 and December 2004, 5,688 people were returned to their alleged countries of origin which included Bangladesh, Egypt, Eritrea, Ghana, Mali, Niger, Nigeria, Pakistan, Sudan and Syria in over 50 charter flights financed partly by Italy. Such operations took place in total neglect of the principle of non-refoulement and without giving the possibility to irregular migrants that were in need of protection to apply for asylum when they arrived in Italy. NGOs and international organizations also report that the conditions of deportation were such that sometimes the very survival of the deportees was in 


\section{A. Triandafyllidou}

danger (Pastore \& Trincheri, 2008). Despite the harsh tactics of the then Berlusconi government, the passage from Libya to Italy had remained a preferred route for the networks smuggling irregular migrants from sub Saharan Africa to Italy and Europe until 2009 while entries through the Canary Islands or the Gibraltar strait were sharply reduced.

After the Inter-ministerial Conference on migration organized in cooperation by the European Union and the African Union in November 2006, the Libyan government had agreed that Italian and Maltese coastguard forces would patrol its northern sea borders with cooperation from the Libyan forces. The then left wing Italian government concluded a protocol on maritime cooperation with Libya (2007), allowing Italian navy vessels to enter Libyan waters in order to patrol the sea border jointly with Libyan authorities. The EU had also offered help to Libya for the control of its vast southern border in the Sahara desert. Italian-Libyan relations were further strengthened through the signature of the Treaty on Friendship, Partnership and Cooperation in August 2008 which promised investments worth US\$ 5 billion and cultural development aid to Libya in return for its cooperation for immigration control (Programma Integra, 2008). Article 19 of the Treaty provided for the implementation of previous agreements, particularly the 2007 Protocol on maritime cooperation and joint sea patrol missions, and the creation of a satellite control system of Libyan land borders, to be realised by Italian companies with Italian and EU funds. This part of the treaty raised important human rights concerns about the fate of the immigrants turned back and left in the desert (Human Rights Watch, 2009). While previous accords had been implemented only in part and had no lasting effect on reducing irregular migrant arrivals, this one was implemented systematically, leading to a dramatic reduction in apprehensions in Italian waters or at the shores of Lampedusa.

The almost complete stop of irregular migration from Libya to Lampedusa and Sicily since 2009 and until January 2011 (Table 2 above) was presented by the Italian government as an important policy victory of the government in its efforts to 'fence off' the country from irregular migrants. The UNHCR (Boldrini, 2010) strongly condemned the Italian accords with Libya, and in particular the forced refoulements at sea, back towards the Libyan coasts, which actually prevented potential asylum seekers from filing an application and returned them to an unsafe country. The Italian government refused these accusations by the UNHCR and other international organizations, even if this controversy has significantly damaged the relationship between the Italian authorities and the UNHCR (Boldrini, 2010). In February 2012, the European Court of Human Rights condemned Italy for its 'push back' operations in 2009 in its decision on the Hirsi et al. vs Italy case ${ }^{2}$.

The externalization of border controls implemented by Italy involved the externalization of asylum policy not however through the creation of extra-territorial reception centres but through fencing border control strategies that involved both the Italian and the Libyan authorities. Thus the islands of Lampedusa and Linosa, which had been for a good part of the 2000s the outer posts of migration control, became 'internal' again and the 'external' dimension was enacted at high seas where irregular migrants and/or asylum seekers were intercepted, transferred to Italian coastguard vessels and taken back to the Libyan coasts or were disembarked to Libyan ships, without Italy exercizing its jurisdiction (as the European Court of Human Rights pointed out in the Hirsi decision) while the migrants were on board Italian coastguard ships and hence within Italy's jurisdiction. Contrary to Spain, Italy did not implement any gate-keeping externalization policies; it did not sign any readmission

\footnotetext{
${ }^{2}$ Hirsi Jamaa v. Italy, App. No. 27765/09 (Eur. Ct. H.R. Feb. 23, 2012).
} 
agreements or imposed any visa requirements on Libya. It simply partly externalized its border control through joint patrolling and for the rest left it to Libya to deal with the 'pushed-back' migrants and asylum seekers.

The beginning of the new decade saw the irregular migrant and asylum seeking flows towards the Canary Islands, Lampedusa and Malta coming nearly to a stop. Despite the NGO and international organizations outcry of Italy's cooperation with Libya, the European Commission had signed a 'cooperation agenda' with the Libyan authorities in October 2010 with a view to improving the management of migration flows and control of the external EU borders in the region. This cooperation agenda included payments from the EU to Libya of about $€ 50$ million to help improve its border management capacity. In addition a 'Framework Agreement' between the EU and Libya was being negotiated with a view to preparing for Libya's readmitting third country nationals who enter the EU after transiting through Libya (Amnesty International, 2010). These developments were seen with growing concern by humanitarian organizations like Amnesty International as Libya has no asylum system and is not a signatory of the Geneva 1951 Convention.

The situation changed dramatically in the first six months of 2011 as the social revolt in Tunisia led nearly 20,000 Tunisians to leave their country for Italy. In addition, about another 20,000 sub-Saharan Africans (UNHCR 2011) arrived in Lampedusa fleeing the war in Libya during the spring and summer of 2011. The Italian government had not prepared the necessary infrastructure for receiving these irregular migrants and asylum seekers. The reception centre in Lampedusa had been dismantled since October 2009 as it was believed that the cooperation with Libya would last and there would be no more significant irregular migration flows there.

The new arrivals were initially presented by the government as a dramatic emergency (Italian Prime Minister Berlusconi has spoken of a 'human tsunami' (Corriere della Sera, 2011; also Triandafyllidou \& Ambrosini, 2011). In early April, the Italian government decided to issue temporary permits (of six month validity) for those who had reached Italian shores before 5 April 2011. ${ }^{3}$ The Italian government probably expected that Tunisian immigrants would head to France, where they had family and friends. This decision caused a crisis in Italian-French relations. Tunisia and Italy signed a Cooperation Agreement on 5 April 2011 which concerned police cooperation and readmission of illegally staying migrants, according to which Tunisian liaison officers would be dispatched to Italy to undertake accelerated repatriation procedures (Campisi, 2011, p. 6). According to the Second Frontex Quarterly Report in 2011, some 1,700 Tunisians were repatriated between 5 April and 23 August 2011. In contrast, those arriving from Libya have sought asylum and have been received as people in need of international protection even if the whole issue caused tensions too.

This most recent phase of the Italian migration control policies shows that externalization had to be reconsidered and thus the fencing policies with Libya (abruptly interrupted by the civil war) were replaced by gate-keeping policies with Tunisia; notably the signature of a new readmission agreement. Interestingly, in this last case, the islands become the internal-external outer post of control as Tunisian authorities are invited to operate on the islands with a view to accelerating the procedures.

\footnotetext{
${ }^{3}$ Up to 6 April 2011, 390 boats had arrived in Italy, with a total of 25,867 undocumented migrants and asylum seekers, mainly Tunisian. In total, up to 6 April 2011, only 10 boats had arrived from Libya (Monzini, 2011).
} 


\section{A. Triandafyllidou}

Most recently, during the fall and winter of 2013, the island of Lampedusa has hit the headlines across Europe and the world as arrivals have picked up again and 350 people lost their lives when their boat sank literally outside the port of Lampedusa in September 2013. Most of the people arriving at Lampedusa and Sicily are actually Syrians fleeing their country in need of international protection. The tragic events at Lampedusa in September 2013 led to notable policy developments including the setting up (by the European Council of 7-8 October 2013) of a Task Force Mediterranean which studies the measures that need to be taken to prevent such losses of human life, to channel asylum seekers in more effective ways and to patrol better the Southern EU sea borders. The first report of the Task Force, issued on 4 December 2013, points to the importance of cooperation with the transit countries, the need for a regional approach to protection and resettlement and the importance of showing solidarity with Member States that bear the brunt of such flows (European Commission 2013). It also of course emphasises the need to reinforcing border surveillance and to combating the smuggling and trafficking of migrants. Interestingly the mayor of Lampedusa, Giusi Nicolini, known in the media for her left-wing orientation and pro-solidarity views, and a right wing Senator (Luigi Manconi) have prepared jointly a proposal submitted to the European Council of 24-25 October 2013 suggesting that there should be asylum seeking processing centres in North Africa which would issue one year permits for international subsidiary protection. Once such a visa would be obtained the person in need of protection would be able to apply to go to a country where s/he may have relatives.

Interestingly these proposals point to the multi-level nature of externalization which seeks to transfer the asylum gate-keeping to third countries while strengthening the local fencing of the EU borders through the Eurosur border surveillance system. The cooperation of transit countries in the fencing remains important and emphasised but it is unclear how much fencing they are expected to do since the Eurosur system is expected to solve all issues through technological efficiency.

\section{Malta}

The Italy-Libya accords affected also the situation of Malta. Malta is the smallest (both in terms of area and population) and most densely populated country in the European Union. The country has a land area of 316 square kilometres and a resident population of about 410,000 . It is situated 90 kilometres south of Sicily, 290 kilometres from the northern coast of Tunisia and 360 kilometres from Libya. In recent years, Malta has experienced irregular migrant and asylum seeker arrivals mainly from sub-Saharan Africa via Libya or Tunisia. The number of such immigrants arriving on the island increased dramatically from 57 in 2001 to 1,686 in 2002 and has remained just below 2,000 people till 2012 included (with the exception of 2003 when figures fell to 502) (Table 3 below). In November 2010, Malta hosted approx. 3,700 African migrants (79 in detention, 2,224 in open centres and 1,400 in the community) according to official statistics released in November 2010, a far cry from over 10,000 immigrants who were estimated to be in Malta in 2008 (Times of Malta, 27 March 2011). Of the 9,554 immigrants that have arrived in Malta in an irregular way during the period 2005-2009, about one third were Somali citizens. The second largest nationality group were Eritreans $(1,259)$, followed by Egyptians (755), Nigerians (652) and Sudanese (596). (Triandafyllidou \& Maroukis, 2012). 
Malta has an extensive Search and Rescue (SAR) area, based on its Flight Information Region, which spans over $250,000 \mathrm{~km}^{2}$ and which effectively means that every boat leaving Libya must pass though Malta's SAR (see Map 1 above). The Maltese Armed Forces only come to the aid of boats in distress in their SAR region and allow others to pass through without intervening. The boats asking for assistance are brought into Maltese ports, where the immigrants aboard are transferred to one of the detention centres.

According to Mainwaring (2008), many of the people apprehended and incarcerated in Malta had no intention of going to the island and indeed no desire to stay there. They were rather looking for ways to move on to Italy and other mainland European countries. Since 2009 Malta has developed a pilot resettlement program (European Relocation Malta, EUREMA) under the aegis of the European Commission (resettling refugees to other EU countries) and with the USA (resettling 500 refugees each year to North America). About 1,000 refugees were resettled to other EU countries during the period 2009-2010 and the program was to come to an end in 2011. However, after the outbreak of the war in Libya, the European Commission renewed the program for one more year. Mainwaring (2008) and several NGO reports (including Amnesty International, the UNHCR, and the European Council for Refugees and Exiles) are particularly critical of the conditions of detention in Malta. Mainwaring also notes that detention in Malta was previously possible for an indefinite period of time. It was reduced to a maximum of 18 months after the visit of a delegation from the Council of Europe in 2007. The data presented in Table 3 below testify to the fact that landings at Malta of irregular migrants and asylum seekers are linked to those of Italy. In 2010 there was a dramatic reduction to only 28 arrivals (similarly to what happened in Lampedusa on the same year); but arrivals increased spectacularly again since 2011 .

Table 3: Arrival of irregular migrants in Malta: 2001-2013.

\begin{tabular}{|l|l|l|l|l|l|l|l|l|l|l|l|l|}
\hline 2001 & $\mathbf{2 0 0 2}$ & $\mathbf{2 0 0 3}$ & $\mathbf{2 0 0 4}$ & $\mathbf{2 0 0 5}$ & $\mathbf{2 0 0 6}$ & $\mathbf{2 0 0 7}$ & $\mathbf{2 0 0 8}$ & $\mathbf{2 0 0 9}$ & $\mathbf{2 0 1 0}$ & $\mathbf{2 0 1 1}$ & $\mathbf{2 0 1 2}$ & $\begin{array}{l}\mathbf{2 0 1 3} \\
\text { (till end } \\
\text { July) }\end{array}$ \\
\hline 57 & 1,686 & 502 & 1,388 & 1,822 & 1,780 & 1,702 & $\mathbf{2 , 7 7 5}$ & 1,397 & 28 & 1,577 & $\mathbf{1 , 8 9 0}$ & 1,294 \\
\hline
\end{tabular}

Source: Data for 2001-2010 from Triandafyllidou \& Maroukis (2012), Table 2.5, p. 43. Data on 2011, retrieved from http://www.crimemalta.com/frontexwatch.htm Data on 2012-2013 retrieved from http://www.independent.com.mt/articles/2013-07-31/news/record-number-ofirregular-migrant-arrivals-for-july-2210660356 Emphasis added.

Malta adopts a peculiar externalization policy to control its borders more effectively, without having to process a disproportionately large number of irregular migrants or asylum seekers. It actually transfers its own sea border control policy to Italy by letting boats from Tunisia and (especially) Libya cross towards Italian coasts. It thus indirectly piggy-backs on Italy's policy which further externalises the control to Libya. 


\section{A. Triandafyllidou}

\section{Greece and the Aegean islands}

The analysis of the position of the southern European islands in the EU migration control and asylum seeking policies cannot be completed without considering the Aegean islands in Greece.

The length of the Greek islands' coasts in the Aegean and their close proximity to the Turkish coast make the policing of this part of the external EU sea border particularly demanding in terms of human resources and technical equipment. The dramatic increase of arrivals at the Greek Turkish sea borders from approximately 4,000 to 5,000 per year in the period 2002-2005, to double the number (just over 9,000) in 2006 - the crisis year for the Canary islands - signalled for the Aegean islands too the start of a new phase in terms of irregular migration inflows towards Greece via Turkey. In 2007 and 2008, the number of apprehensions doubled each year (from 9,000 in 2006 to 16,000 in 2007 to more than 50,000 in 2010), but fell in 2012 and was reduced to a trickle in 2013 (see Table 4). ${ }^{4}$

\section{Table 4: Greek-Turkish border apprehensions: 2008-2013.}

\begin{tabular}{|c|c|c|c|c|c|c|}
\hline Border areas & $\mathbf{2 0 0 8}$ & $\mathbf{2 0 0 9}$ & $\mathbf{2 0 1 0}$ & $\mathbf{2 0 1 1}$ & $\mathbf{2 0 1 2}$ & $\mathbf{2 0 1 3 *}$ \\
\hline Land Border & 14,461 & 8,787 & 47,088 & 54,974 & 30,433 & 585 \\
\hline Sea Border & 30,149 & 27,685 & 6,204 & 1,030 & 3,651 & 5,579 \\
\hline Total Apprehensions & 44,610 & 36,472 & 52,269 & 56,004 & 34,084 & 6,834 \\
\hline
\end{tabular}

Source: Ministry of Public Order \& Citizen Protection (2012). * Data for Jan-Aug 2013.

The number of apprehensions generally indicates not only irregular migration or asylum seeking pressures at the borders but also the enforcement efforts of the authorities. Greece has beefed up its border controls since 2007. In the autumn of 2007, the Greek border authority deployed 200 additional officers in the Aegean sea. In addition, Frontex has been operating in Greece since 2006 albeit with increasing intensity in the period 2010-2012. The joint operation Poseidon has become now the largest Frontex operation in the Mediterranean. It includes the first time ever deployment of Frontex's Rabit (Rapid Border Intervention Teams, 175 officers were sent to the Greek Turkish land border in late October and November 2010 and stayed there until March 2011). In addition, Frontex collaborates in Project Attica which operates in the area of voluntary returns, and has six long-term stationed focal points.

Maroufof (2011) argues that the points of approach/disembarkation of irregular entries from Turkey into Greece are shifting constantly. Arrivals have been registered at almost any possible place along the eastern coast of Greece (see Map 1 above). However, according to a

\footnotetext{
${ }^{4}$ These sudden changes in the inflows of irregular migrants and asylum seekers from the Greek Turkish sea border to the north-eastern land border between the two countries along the Evros river show a change in the irregular migration and asylum-seeking routes in the region. State authorities and Frontex have attributed the change to the presence and operations of FRONTEX in the Aegean. However, this does not seem plausible as FRONTEX has been operating in the Aegean sea for several years earlier without stemming the increase of irregular migration flows into the country through the Greek Turkish sea border and the Aegean islands. The completion of the de-mining along the Greek Turkish land border along the Evros river explains more convincingly this shift in the flows (also Pro Asyl, 2012).
} 
report of the Ministry of Maritime Affairs (2009) during the period between 2006 and 2008, $95 \%$ of those entering from Turkey were apprehended in the islands of Eastern Aegean, and mainly in Lesvos, Chios, Leros and Kos. The same trend was observed in 2009. The smuggling routes from Egypt, mainly to Crete, have been substantially blocked by the Greek Coastguard since 2008 and only a few entries were registered there.

Those apprehended at the Greek Turkish borders are seldom sent back to their countries of origin or Turkey. Greece signed a Readmission Protocol with Turkey in 2002. This Protocol however is not implemented in reality. During the period 2006-2010, Greece presented 3,431 readmission requests to Turkey, in the context of this Protocol, concerning 62,816 people (Hellenic Police, 2011). Of those, 7,359 were accepted for readmission by Turkish authorities, but only 1,281 were effectively returned to Turkey. The reason is the overall reluctance of Turkey to actually implement the Protocol. While the Protocol foresees three readmission routes (via the airports of Athens and Istanbul, a crossing point at the Greek Turkish border along the Evros river, and the port of Izmir for Turkey and the port of Rhodes for Greece), only the land border readmission route is actually used. Turkey continues to refuse to use the port of Izmir as a readmission location, claiming that it does not dispose of the necessary human and material resources required for the task (Triandafyllidou \& Maroukis, 2012, pp. 66, 78).

The externalization of migration and asylum control policies in the region has had more to do with fencing strategies through the operation of Frontex in the region and the building of a fence. Attempts to also establish gate-keeping policies (such as readmission to Turkey) were not successful: Turkey signed the Protocol and thus formally accepted the externalization of the Greek Turkish sea border control; but, in practice, it has resisted this externalization and did not actually implement the Protocol.

In the next section of this paper, I seek to assess the relative success and failure of the different externalization policies adopted by the four countries studied as well as to consider the overall role of the southern European islands in EU migration and asylum seeking control policies.

\section{Conclusion}

The southern European islands attract a large number of immigrants and asylum seekers mostly as stepping stones to the continent rather than as destinations as such. Their strategic location and role is largely due to the very existence of the EU. They become pivotal areas of externalization: they are at once part of the internal and external dimension of EU migration control and asylum policy and are involved as both recipients and agents (or should we say victims and perpetrators) of a complex web of externalization policies and practices within the $\mathrm{EU}$ and from the EU to third countries.

Often, the main concern for Spain, Italy, Malta and Greece is to keep migration control off their island shores. They thus adopt readmission agreements and joint border control operation at high seas in order to prevent migrants and asylum seekers from even reaching the islands. Thus, control policies are driven out and away from the EU territory either to the high seas or possibly to third countries. Indeed our analysis shows that externalizing gate-keeping has been overall successful with the exception of the Greek Turkish readmission Protocol. Maximum effectiveness is achieved when combined with successful and stronger fencing efforts which however can only take place within the EU territory or at sea borders as the brief experience of Italy and Libya revealed the problematic nature of externalizing fencing, and the 


\section{A. Triandafyllidou}

challenges that this poses particularly for international protection issues. Thus the successful recipe reiterated in the Task Force Mediterranean latest report points to multi-level externalization of gate-keeping functions through visa regimes, readmission agreements and potentially asylum seeking processing at transit countries combined with higher fencing at green and blue EU borders. At the same time, however, our analysis shows that fencing mainly leads to the re-direction of flows, as the case of Greece suggests; from the green borders to the sea borders, or indeed to a diversion of routes towards other EU external borders, notably those of Bulgaria with Turkey (Medecins Sans Frontieres, 2013; UNHCR, 2013).

Interestingly though we note that externalization is multi-levelled and takes place also within the EU. First, countries farther north and west externalize the EU migration and asylum control protocol to the islands in the south. This happens through the Dublin II (and III) Regulation and the related implementation of the 'first safe country' principle. In other words it happens through gate-keeping policies. Second, there are the manipulations of the Schengen area provisions so that multiple fencing takes place: when Italy gave temporary permits to displaced Tunisians, France threatened to close its border with Italy to avoid that these Tunisians with temporary stay papers could migrate to France. Third, in the case of the Aegean and the Canary islands, this intra-EU externalization process is also enacted through Frontex participation in fencing operations: Frontex officers operate at the Canary and African coasts to prevent migrants from arriving to the islands at all. Frontex officers in the Maltese coasts and at the Aegean islands transform the islands as the places where European control is externalized. The islands are the places where fencing takes places, but they are made to be the loci of fencing because of the gate-keeping policies enacted at the EU level.

This paper points to the need for framing our understanding of externalization policies and practices within a wider web of multi-level governance schemes that engage EU and non EU actors, at different combinations and for different types of policies. The distinction between internal and external externalization as well as between fencing and gate-keeping policies and practices is important to appreciate the full range of these policy dynamics and the challenges that they raise both in terms of effectiveness of migration control and in terms of challenges for human rights and international protection obligations.

\section{References}

Amnesty International. (2010). Seeking safety. Finding fear. Refugees, asylum-seekers and migrants in Libya and Malta. 14 December. Retrieved from http://www.amnesty.org/en/library/asset/REG01/004/2010/en/d0e71b60-71ec-4c4b8b2f-d03a881b90f6/reg010042010en.pdf

Bernardie-Tahir, N., \& Schmoll, C. (2014). Opening up the island: a 'counter-islandness' approach to migration in Malta. Island Studies Journal, 9(1), pp. 43-56.

Boldrini, L. (2010). Tutti indietro. Milano: Rizzoli.

Caffio, F. (2011). L'emergenza immigrazione riaccende la tensione tra Italia e Malta. Retrieved from http://www.affariinternazionali.it/articolo.asp?ID=1440

Carling, J. (2007a). Unauthorized migration from Africa to Spain. International Migration, 45(4), pp. 3-37.

Carling, J. (2007b). Migration control and migrant fatalities at the Spanish African borders. International Migration Review, 41(2), pp. 316-343. 
Carling, J., \& Hernandez-Carretero, M. (2011). Protecting Europe and protecting migrants? Strategies for managing unauthorized migration from Africa. British Journal of Politics and International Relations, 13(1), pp. 42-58.

European Council. (1999). Presidency conclusions. Brussels, 10 and 11 December. Retrieved from http://www.europarl.europa.eu/summits/hell_en.htm

European Council. (2004). Presidency conclusions. Brussels, 4/5 November 2004.

European Council. (2010). The Stockholm Program: an open and secure Europe serving and protecting citizens (2010/C 115/01). Retrieved from http://eurlex.europa.eu/LexUriServ/LexUriServ.do?uri=OJ:C:2010:115:0001:0038:en:P DF

Freeman, G. (1995). Modes of immigration politics in liberal democratic states. International Migration Review, 29(4), pp. 881-902.

Fundamental Rights Agency. (2011). Coping with a fundamental rights emergency: The situation of persons crossing the Greek land border in an irregular manner. Vienna: Fundamental Rights Agency.

Guiraudon, V., \& Lahav, G. (2000). The state sovereignty debate revisited: the case of migration control. Comparative Political Studies, 33(2), pp. 163-195.

European Commission. (2013). Communication from the Commission to the European Parliament and the Council on the work of the Task Force Mediterranean. Brussels, 4 December. COM(2013) 869 final. Retrieved from http://ec.europa.eu/dgs/homeaffairs/what-isnew/news/news/docs/20131204_communication_on the work_of the task force med iterranean_en.pdf

European Parliament. (1987). Resolution on the right of asylum. Doc. 12-227/86, 12 March.

Gonzalez Enriquez, C. (2008). Spain. CLANDESTINO Project report. Retrieved from http://clandestino.eliamep.gr

Gonzalez Enriquez, C. (2009). Spain, the cheap model: irregularity and regularization as immigration management policies. European Journal of Migration and Law, 11(1), pp. $139-157$.

Hellenic Police. (2011). Retrieved from http://www.astynomia.gr/images/stories/2011/statistics2011/0102aithm-epan20062010.pdf

Human Rights Watch, (2009). Pushed back, pushed around: Italy's forced return of boat migrants and asylum seekers, Libya's mistreatment of migrants and asylum seekers, 21 September. Retrieved from http://www.hrw.org/features/italylibya-pushed-backpushed-around

Mainwaring, C. (2008). Malta. Paper presented at the Irregular Transit Migration in the European Space Conference, Koc University, Istanbul, 18-20 April. Retrieved from http://www.compas.ox.ac.uk/fileadmin/files/pdfs/Non_WP_pdfs/Tranist_Migration_in Europe Koc_University_10\%20Cetta\%20Mainwaring.pdf

Maroufof, M. (2011). Background report on the Treatment of Migrants at the EU External Borders, Athens, ELIAMEP, March 2011, unpublished report. 


\section{A. Triandafyllidou}

Medecins Sans Frontieres. (2013). Bulgaria: Syrian refugees face appalling conditions. 21 November. Retrieved from http://www.msf.org/article/bulgaria-syrian-refugees-faceappalling-conditions

Ministry of Maritime Affairs Islands and Fisheries, Security Division. (2009). Illegal migration

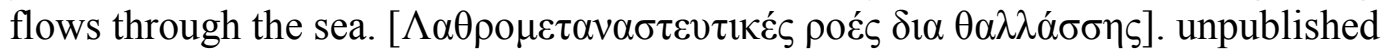
report, Athens.

Klepp, S. (2010). A contested asylum System: the European Union between refugee protection and border control in the Mediterranean Sea. European Journal of Migration \& Law, 12(1), pp. 1-21.

Lavenex, S. (1999). Safe third countries: Extending the EU asylum and immigration policies to Central and Eastern Europe. Budapest, Hungary: Central European University Press.

Lavenex, S. (2006). Shifting up and out: the foreign policy of European immigration control. West European Politics, 29(2), pp. 329-350.

Papagianni, G. (2006). Institutional and policy dynamics of EU migration law. Amsterdam: Martinus Nijhoff.

Programma Integra. (2008). Trattato di amicizia, partenariato e cooperazione tra la Repubblica italiana e la grande Giamahiria araba libica popolare socialista. [Treaty of friendship, partnership and cooperation between Republic of Italy and Socialist People's Republic of Libya]. Retrieved from

http://www.programmaintegra.it/modules/dms/file retrieve.php?function=view\&obj id $=2083$

Triandafyllidou, A., \& Ambrosini, M. (2011). Irregular immigration control in Italy and Greece: strong fencing and weak gate-keeping serving the labour market. European Journal of Migration and Law, 13(2), pp. 251-273.

Triandafyllidou, A., \& Ilies, M. (2010). EU policies on irregular migration. In A. Triandafyllidou (ed.) Irregular migration in Europe: Myths and realities (pp. 23-41). Aldershot, UK: Ashgate.

Triandafyllidou, A., \& Maroukis, T. (2012). Migrant smuggling: Irregular migration from Asia and Africa to Europe. London: Palgrave.

UNHCR (2011). Jolie e Guterres a Lampedusa alla vigilia della GMR. Retrieved from http://www.unhcr.it/news/dir/26/view/1003/jolie-e-guterres-a-lampedusa-alla-vigiliadella-gmr-2011-100300.html

UNHCR (2013). Bulgaria's asylum centres bursting at the seams as Syrian refugees enter Europe. 17 September. Retrieved from http://www.unhcr.org/52384d359.html

Vogel, D. (2000). Migration control in Germany and the United States. International Migration Review 34(2), pp. 390-422. 